\title{
MODEL PENGEMBANGAN USAHA BUDIDAYA RUMPUT LAUT (Eucheuma cottonii) DENGAN PENDEKATAN CAUSAL LOOP DIAGRAM (STUDI KASUS DI PANTAI CIPATUJAH KABUPATEN TASIKMALAYA)
}

\author{
Model on Seaweed Business Development using Causal Loop Diagram Approach \\ (Case Study at Cipatujah Beach Tasikmalaya District)
}

\author{
Wahyu Kristian Sugandi1 ${ }^{1, *}$, Guyup Mahardian Dwi Putra ${ }^{2}$ \\ ${ }^{1}$ Fakultas Teknologi Industri Pertanian, Universitas Padjadjaran Bandung \\ ${ }^{2}$ Program Studi Teknik Pertanian Fakultas Teknologi Pangan dan Agroindustri \\ Universitas Mataram \\ Email $^{*}$ : sugandiwahyu@gmail.com \\ Diterima : 1 Februari 2017 \\ Disetujui : 20 Februari 2017
}

\begin{abstract}
Cipatujah Beach in Tasikmalaya Regency is one place that has potential in the development of seaweed, due to its topography and natural conditions that exist there suitable for the cultivation of seaweed. World's seaweed demand as raw material for food industry and medicine continues to rise, therefore an approach using causal loop diagrams methods has been applied to model the development of seaweed business on Cipatujah Beach in Tasikmalaya District. The results of this study indicate that the first scenario is the best result compared to the second and third scenario. Where by increasing seed weight on the initial stocking to $30 \mathrm{~kg}$ per lane in each planting, the production of the 25th harvest increased by $33.3 \%$ compared with the base model scenarios. While after the development, the profit rose to $32.5 \%$, compared with the base model scenarios. It is expected that the first scenario could be used by investors and local governments as a basis to develop business on seaweed, in order to improve the welfare of coastal communities at Cipatujah Beach in Tasikmalaya District.
\end{abstract}

Keywords: Cipatujah Beach, scenario, seaweed

\begin{abstract}
ABSTRAK
Pantai Cipatujah Kabupaten Tasikmalaya merupakan salah satu tempat yang berpotensi dalam pengembangan usaha rumput laut mengingat topografi dan kondisi alam yang ada disana memungkinkan untuk pembudidayaan rumput laut. Permintaan dunia akan kebutuhan rumput laut sebagai bahan baku industri makanan dan obat-obatan terus meningkat, untuk itu telah dilakukan pendekatan model pengembangan usaha rumput laut di pantai Cipatujah Kabupaten Tasikmalaya dengan metode causal loop diagram. Hasil dari penelitian ini menunjukkan bahwa skenario ke-1 merupakan hasil yang paling baik dibandingkan dengan skenario ke-2 dan ke-3. Dimana dengan ditingkatkannya bobot bibit pada penebaran awal menjadi $30 \mathrm{~kg}$ per jalur pada tiap penanaman, maka kenaikan produksi pada panen ke-25 sebesar 33,3 \% jika dibanding dengan skenario model dasar. Sedangkan keuntungan setelah pengembangan naik menjadi 32,5\% dibandingkan dengan skenario model dasar. Diharapkan skenario ke-1 ini dapat digunakan oleh investor dan pemerintah setempat
\end{abstract}


sebagai dasar untuk membangun usaha rumput laut guna meningkatkan kesejahteraan masyarakat pantai Cipatujah Kabupaten Tasikmalaya.

Kata kunci: Pantai Cipatujah, rumput laut, skenario

\section{PENDAHULUAN}

Luas perairan laut Indonesia serta keragaman jenis rumput laut merupakan cerminan dari potensi rumput laut Indonesia. Dari 782 jenis rumput laut di perairan Indonesia, hanya 18 jenis dari 5 genus (marga) yang sudah diperdagangkan dan hanya 2 genus yang sudah dibudidayakan. Euchema cottonii, yg dikenal juga dengan nama latin Kappahycus alvarezii, adalah salah satu jenis rumput laut yang sudah di budidayakan di perairan Indonesia.

E. cottonii dibudidayakan untuk diambil esktrak karaginannya, yang digunakan pada berbagai macam aplikasi, terutama pada industri makanan dan obatobatan (farmasi). Karaginan mempunyai manfaat sebagai pengatur keseimbangan (stabilizer), pengemulsi, pengental, dan membuat suatu bahan menjadi jelly (gelling agent).

Menurut para ahli dari ACIAR (Australian Center for International Agriculture Research) yang berkumpul pada Fisheries Meeting yang diadakan di New Caledonia pada bulan April 2006, status industri rumput laut E. Cottonii bergantung dari persediaan dan permintaan (supply and demand), dimana pada saat ini terjadi permintaan yang tinggi terhadap rumput laut $E$. Cottonii karena kelangkaan persediaan bahan mentah jenis ini (Anonim, 2006). Dunia industri memprediksi permintaan produk karaginan akan naik sekitar 4-6 \% pertahun karena meningkatnya penggunaan di negara Asia dan Amerika Latin, juga bersamaan dengan itu produk dari hewan gelatin sudah tidak lazim lagi digunakan dan sebagai penggantinya digunakan karaginan.

Data total produksi dunia pertahun untuk E.Cottonii adalah 220.000 ton, dimana $90 \%$ dihasilkan oleh Filipina dan
Indonesia. Dari total produksi dunia ini, Indonesia menghasilkan total produksi $E$. Cottonii pertahun sebanyak 38.000 ton (1995-1999), sedangkan Filipina menghasilkan 115.000 ton pertahun. Angka ini menunjukkan produksi Indonesia masih sangat kecil dibandingkan produksi Filipina (Anggadiredja, dkk., 2006). Masih menurut Anggadiredja, dkk., produksi rata-rata selama 5 tahun (19951999) sebesar 38.000 ton pertahun dipanen dari lahan seluas kurang lebih 2.500 ha (tambak dan laut). Dengan demikian, baru termanfaatkan sebesar $9,7 \%$ dari luas potensi lahan yang ada.

Oleh karena tingginya permintaan dunia akan rumput laut, maka perlu dilakukan usaha pengembangan rumput laut pada daerah-daerah yang potensial dimana masih banyak lahan yang belum optimal penggunaannya.

Pantai Cipatujah yang terletak di Kabupaten Tasikmalaya adalah termasuk salah satu daerah di Indonesia yang berpotensial untuk dijadikan lahan budidaya rumput laut E. Cottoonii. Pantai Cipatujah yang terletak di desa Cipatujah memiliki luas \pm 115 hektar dan terletak \pm $74 \mathrm{~km}$ dari pusat kota Tasikmalaya dengan jumlah penduduk sekitar 54.766 jiwa yang terdiri dari 16.619 KK. Dengan panjang garis pantai sekitar $1 \mathrm{~km}$ dan kondisi perairan yang relatif masih bersih sangat cocok menjadi lahan budidaya rumput laut. Lokasi ini terletak di pantai selatan pulau Jawa yang merupakan lokasi ideal karena perairannya masih bersih dari limbah industri dan rumah tangga. Ombak yang tidak terlalu besar dan pengaruh angin kencang lebih kecil sangat menentukan dalam tingkat keberhasilan dalam budidaya rumput laut ini. Dampak dari bisnis rumput laut juga bisa meningkatkan pendapatan penduduk lokal yang umumnya merupakan nelayan ikan 
sekaligus petani rumput laut. Oleh karena itu, maka perlu dilakukan usaha pengembangan budidaya rumput laut di daerah ini. Adapun pendekatan model yang dipilih dalam usaha pengembangan budidaya rumput laut ini adalah dengan pendekatan Model CLD (Causal Loop Diagram). Model ini dipilih karena mempertimbangkan kompleksitas dinamis. Model CLD menekankan perhatiannya kepada hubungan sebab-akibat antar komponen sistem yang digambarkan dalam suatu diagram berupa garis lengkung yang berujung tanda panah yang menghubungkan antara komponen sistem yang satu dengan lainnya. Ujung panah dibubuhi tanda huruf "S" yang menandakan bahwa jika komponen yang mempengaruhi atau sebagai penyebabnya berubah atau meningkat maka komponen yang dipengaruhinya akan berubah atau meningkat juga dan tanda huruf "O" menandakan akibatnya berlawanan dengan pengertian bila komponen yang mempengaruhi meningkat maka komponen yang dipengaruhinya menurun. Pendekatan melalui model CLD mempunyai beberapa keuntungan khususnya dalam pengembangan budidaya rumput laut antara lain:

1. Dapat melihat permasalahan secara menyeluruh, baik dari segi cakupan dan waktu sehingga dapat mencegah pemikiran yang sempit.

2. Gambaran rantai hubungan sebabakibat dapat membuat lebih eksplisit dan dasar pemikiran akan lebih baik.

3. Memungkinkan efektifitas komunikasi dapat berjalan dan perwujudan kerja sama tim akan lebih baik.

4. Membantu mengeksplorasi alternatif kebijakan dan keputusan sehingga konsekuensinya yang terjadi dapat diantisipasi lebih awal.

5. Memungkinkan keberadaan posisi yang baik untuk mengambil keputusan.

\section{Tujuan Penelitian}

1. Membuat suatu model pengembangan usaha budidaya rumput laut (Eucheuma cottonii) di pantai Cipatujah Kabupaten Tasikmalaya dengan pendekatan Causal Loop Diagram (CLD).

2. Merancang 3 (tiga) Skenario dengan cara meningkatkan penambahan bobot, penambahan modal dan penambahan jalur.

\section{BAHAN DAN METODE}

Bahan yang dibutuhkan untuk penelitian ini software program Powersim dan seperangkat komputer. Metode yang digunakan adalah analisis deskripsi. Adapun tahapan penelitian adalah sebagai berikut:

1. Survei lapangan tentang luas wilayah dan topografi Pantai Cipatujah yang dapat dijadikan budidaya rumput laut.

2. Identifikasi masalah sehingga menghasilkan suatu operasi dari sistem yang dianggap efektif.

3. Pendekatan systems archetypes yang dipilih pada kasus pengembangan model usaha rumput laut di Pantai Cipatujah Kabupaten Tasikmalaya adalah Growth and Underinvestment karena pada kasus ini menitikberatkan pada investasi modal.

4. Analisis semua faktor untuk mencapai tujuan yang telah ditetapkan.

5. Membuat rancangan diagram lingkar sebab akibat (causal loop diagram).

6. Membuat diagram input-output model pengembangan usaha rumput laut.

7. Membuat permodelan sistem dengan flow diagram.

\section{HASIL DAN PEMBAHASAN}

Pemodelan usaha pengembangan rumput laut di Pantai Cipatujah akan sangat membantu para stakeholder dalam mengindetifikasi komponen apa saja dalam sistem yang akan berpengaruh dalam meningkatkan produksi rumput laut serta faktor pembatasnya. Beberapa komponen 
yang berpengaruh adalah luas lahan serta modal.

Perairan Pantai Cipatujah menyediakan lahan seluas $8000 \mathrm{~m}^{2}$ yang potensial untuk budidaya rumput. Sedangkan luas lahan yang yang dibutuhkan untuk budidaya rumput laut adalah $4000 \mathrm{~m}^{2}$. Pada lokasi budidaya ini, terdapat 225 jalur dimana pada tiap jalur terdapat 200 ikat bibit rumput laut dengan berat bibit $50 \mathrm{gr} / \mathrm{ikat}$ atau $10 \mathrm{~kg} / \mathrm{jalur}$. Penggunaan lahan perjalur adalah $17,8 \mathrm{~m}^{2}$. Pada panen pertama, produksi rumput laut adalah $80 \mathrm{~kg}$ berat basah/jalur atau $8,9 \mathrm{~kg}$ berat kering/jalur. Modal yang dikeluarkan terbagi atas 2, yaitu modal untuk bibit dan sarana perjalur. Biaya bibit diasumsikan Rp 15.000/jalur serta biaya sarana adalah Rp 20.000/jalur. Sarana termasuk tali, pelampung dan jangkar yang dibutuhkan pada tiap jalur. Tenaga kerja yang dibutuhkan adalah 1 orang per 11 jalur dengan upah diasumsikan $\mathrm{Rp}$ $1.500 /$ jalur/orang pada setiap panen.

Metode budidaya yang digunakan adalah metode rawai atau longline (Gambar 1). Metode ini merupakan cara yang paling banyak diminati petani rumput laut karena disamping fleksibel dalam pemilihan lokasi, juga biaya yang dikeluarkan lebih murah.

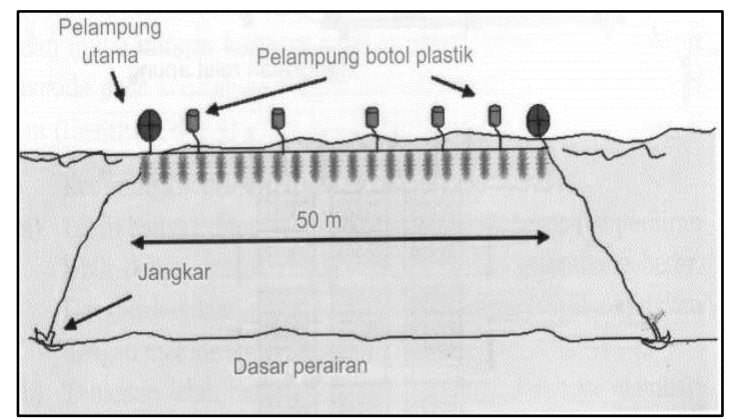

Gambar 1. Metode Rawai (tampak samping) (Sumber: Anggadiredja, 2006)

Berdasarkan pernyataan kebutuhan para stakeholder dan masalah yang harus dipecahkan untuk memenuhi kebutuhan tersebut maka dibuat hubungan antar beberapa variabel pada pengembangan diagram lingkar sebab akibat (Gambar 2).

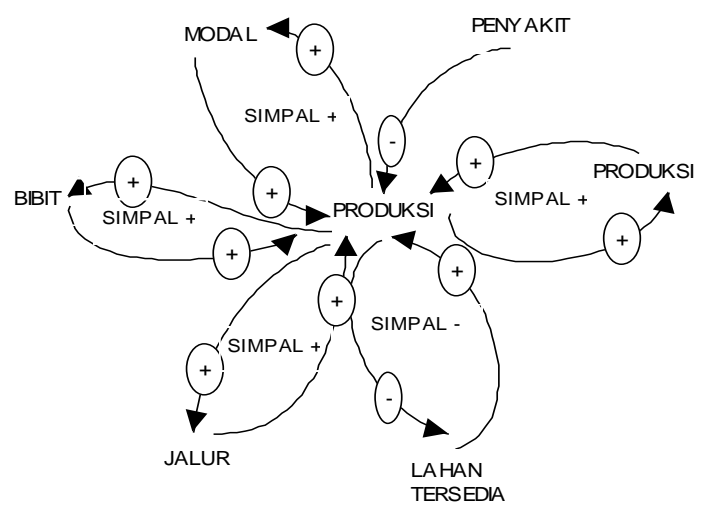

Gambar 2. Diagram Lingkar Sebab-Akibat (Causal Loop Diagram) Usaha

Pengembangan Budidaya Rumput Laut (Eucheuma cottonii) di Pantai Cipatujah Kabupaten Tasikmalaya

Pada diagram lingkar causal loop usaha budidaya E. Cottonii terdapat pengaruh positif dan negatif, dimana pada umumnya pengaruh positif mendominasi. Pengaruh negatif hanya terdapat pada komponen penyakit, dimana semakin sering rumput laut terserang penyakit, maka produksi akan semakin berkurang. Di sisi lain produksi juga berpengaruh negatif terhadap lahan yang tersedia, dimana semakin meningkat produksi tentu saja lahan yang tersedia juga semakin berkurang. Komponen lainnya berpengaruh positif adalah dengan semakin meningkatnya modal maka produksi akan semakin meningkat pula.

Identifikasi sistem diagram lingkar sebab-akibat kemudian diinterpretasikan untuk membuat konsep flow chart diagram input-output. Diagram input-output merepresentasikan input lingkungan, input terkontrol dan tidak terkontrol, output dikehendaki dan tidak dikehendaki, serta manajemen pengendalian (umpan balik). Sedangkan paramater rancangan sistem dipresentasikan sebagai kotak hitam (black box) pada tengah diagram, yang menunjukkan terjadinya proses transformasi input menjadi output. Diagram input-output desain sistem pengembangan usaha budidaya $E$. cottonii 
berdasarkan data di lapangan disajikan pada Gambar 3.

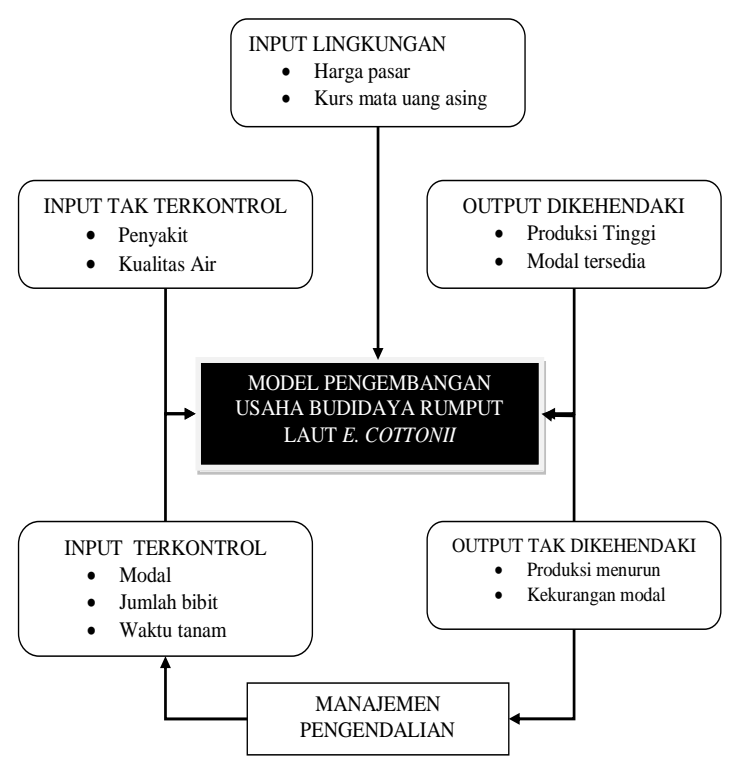

Gambar 3. Diagram Input-Output Model Pengembangan Usaha Budidaya Rumput Laut (Eucheuma cottonii) di Pantai Cipatujah Kab. Tasikmalaya

\section{Permodelan Sistem dengan Flow Diagram}

Model adalah simplifikasi dari sistem yang dihadapi, model dibuat atau digunakan karena akan lebih mudah untuk bekerja dengan model daripada keadaan sesungguhnya (Hardjomidjojo, 2004). Simulasi model adalah peniruan perilaku suatu gejala atau proses dalam membuat suatu analisis dan peramalan perilaku gejala atau proses tersebut dimasa yang akan datang (Muhammadi, 2001).

Permodelan pengembangan usaha budidaya rumput laut $E$. cottonii di Pantai Cipatujah dibuat dengan menggunakan software program Powersim Diagram alir model pengembangan usaha budidaya rumput laut E.cottonii dapat disajikan pada Gambar 4.

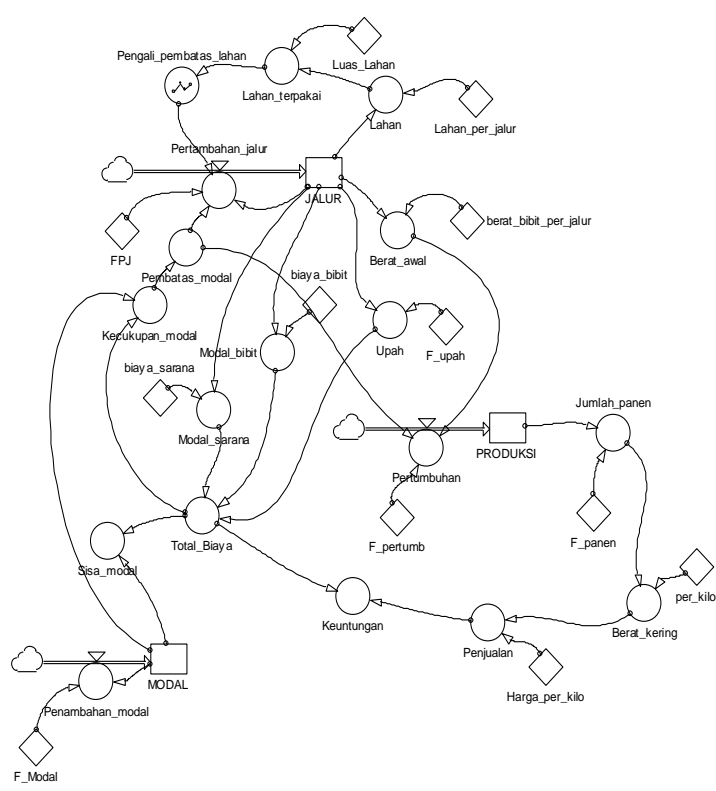

Gambar 4. Model Pengembangan Usaha Budidaya Rumput Laut Eucheuma cottonii di pantai Cipatujah, Kab. Tasikmalaya

\section{Keterangan Persamaan Powersim:}

aux Berat_awal $=$ jalur*berat bibit perjalur const berat_bibit_per_jalur $=10 \mathrm{~kg}$

aux Berat_kering $=$ Jumlah panen* perkilo

const biaya_bibit $=0$

const biaya_sarana $=\operatorname{Rp} 20.000$

const F_Modal $=0.1$

const F_panen $=0.6$

const F_pertumb $=0.8$

const $\quad$ F_upah $=\operatorname{Rp} 1500$

const $\quad \mathrm{FPJ}=0.2$

const Harga_per_kilo $=\mathrm{Rp} 6000$

level JALUR $=225$

aux Jumlah_panen $=$ produksi $*$ F.panen

aux Kecukupan_modal $=$ modal $/$ total

biaya

aux $\quad$ Keuntungan $=$ penjualan - total biaya

aux $\quad$ Lahan $=$ jalur*lahan per jalur

const Lahan_per_jalur $=17.8 \mathrm{~m} 2$

aux Lahan_terpakai $=$ lahan/luas lahan

const Luas_Lahan $=25.000 \mathrm{~m} 2$

level MODAL $=\operatorname{Rp} 6.000 .000$

aux Modal_bibit = jalur*biaya bibit

aux Modal_sarana = jalur*biaya sarana

aux Pembatas_modal $=\mathrm{IF}$ (kecukupan

modal $<1,0,1)$

aux Penambahan_modal $=$

modal*F.modal

aux Pengali_pembatas_lahan =

Graph(lahan terpakai, $0.00,0.10$,

$[0.99,0.8,0.58,0.45,0.38,0.3,0.23,0.16,0.09,0.0$

5,0"min:0,max"] 
aux Penjualan $=$ berat kering*harga

perkilo

const per_kilo $=0.8$

aux Pertambahan_jalur $=$

jalur*FPJ*pengali pembatas lahan*pembatas modal

aux $\quad$ Pertumbuhan $=($ berat

awal*F.tumbuh)*pembatas modal

level PRODUKSI $=0$

aux Sisa_modal $=$ modal - total biaya

aux Total_Biaya $=$ modal bibit + modal

sarana + upah

aux $\quad$ Upah $=($ jalur/11)*F.upah

spec start $=0.00000$

spec stop $=25.00000$

spec $\mathrm{dt}=1.00000$

\section{Konsep Model}

Permodelan yang digunakan untuk pengembangan usaha rumput laut E.Cottonii di Pantai Cipatujah adalah untuk memprediksi 25 kali panen ke depan atau selama 5 tahun ke depan $(1$ tahun $=5$ kali panen). Kinerja atau keberhasilan model dilihat dari peningkatan produksi dengan parameter modal, berat bibit per jalur, serta jumlah jalur yang dapat digunakan sebagai faktor penggerak peningkatan produksi. Simulasi model dasar yang dibuat adalah tanpa pengembangan, yaitu tanpa meningkatkan modal, berat bibit per jalur serta jumlah jalur (Tabel 1)

Tabel 1. Hasil simulasi jumlah modal, total biaya, berat kering dan keuntungan selama 25 kali panen (tanpa upaya pengembangan)

\begin{tabular}{|r|r|r|r|r||}
\hline$\{$ PANEN:?\} & MODAL & Total_Biaya & Berat_kering & \multicolumn{1}{|c|}{ Keuntungan } \\
\hline 1 & $6,000,000.00$ & $4,530,681.82$ & 864.00 & $653,318.18$ \\
\hline 2 & $6,000,000.00$ & $4,530,681.82$ & $1,728.00$ & $5,837,318.18$ \\
\hline 3 & $6,000,000.00$ & $4,530,681.82$ & $2,592.00$ & $11,021,318.2$ \\
\hline 4 & $6,000,000.00$ & $4,530,681.82$ & $3,456.00$ & $16,205,318.2$ \\
\hline 5 & $6,000,000.00$ & $4,530,681.82$ & $4,320.00$ & $21,389,318.2$ \\
\hline 6 & $6,000,000.00$ & $4,530,681.82$ & $5,184.00$ & $26,573,318.2$ \\
\hline 7 & $6,000,000.00$ & $4,530,681.82$ & $6,048.00$ & $31,757,318.2$ \\
\hline 8 & $6,000,000.00$ & $4,530,681.82$ & $6,912.00$ & $36,941,318.2$ \\
\hline 9 & $6,000,000.00$ & $4,530,681.82$ & $7,776.00$ & $42,125,318.2$ \\
\hline 10 & $6,000,000.00$ & $4,530,681.82$ & $8,640.00$ & $47,309,318.2$ \\
\hline 11 & $6,000,000.00$ & $4,530,681.82$ & $9,504.00$ & $52,493,318.2$ \\
\hline 12 & $6,000,000.00$ & $4,530,681.82$ & $10,368.00$ & $57,677,318.2$ \\
\hline 13 & $6,000,000.00$ & $4,530,681.82$ & $11,232.00$ & $62,861,318.2$ \\
\hline 14 & $6,000,000.00$ & $4,530,681.82$ & $12,096.00$ & $68,045,318.2$ \\
\hline 15 & $6,000,000.00$ & $4,530,681.82$ & $12,960.00$ & $73,229,318.2$ \\
\hline 16 & $6,000,000.00$ & $4,530,681.82$ & $13,824.00$ & $78,413,318.2$ \\
\hline 17 & $6,000,000.00$ & $4,530,681.82$ & $14,688.00$ & $83,597,318.2$ \\
\hline 18 & $6,000,000.00$ & $4,530,681.82$ & $15,552.00$ & $88,781,318.2$ \\
\hline 19 & $6,000,000.00$ & $4,530,681.82$ & $16,416.00$ & $93,965,318.2$ \\
\hline 20 & $6,000,000.00$ & $4,530,681.82$ & $17,280.00$ & $99,149,318.2$ \\
\hline 21 & $6,000,000.00$ & $4,530,681.82$ & $18,144.00$ & $104,333,318$ \\
\hline 22 & $6,000,000.00$ & $4,530,681.82$ & $19,008.00$ & $109,517,318$ \\
\hline 23 & $6,000,000.00$ & $4,530,681.82$ & $19,872.00$ & $114,701,318$ \\
\hline 24 & $6,000,000.00$ & $4,530,681.82$ & $20,736.00$ & $119,885,318$ \\
\hline 25 & $6,000,000.00$ & $4,530,681.82$ & $21,600.00$ & $125,069,318$ \\
\hline & & & & \\
\hline
\end{tabular}

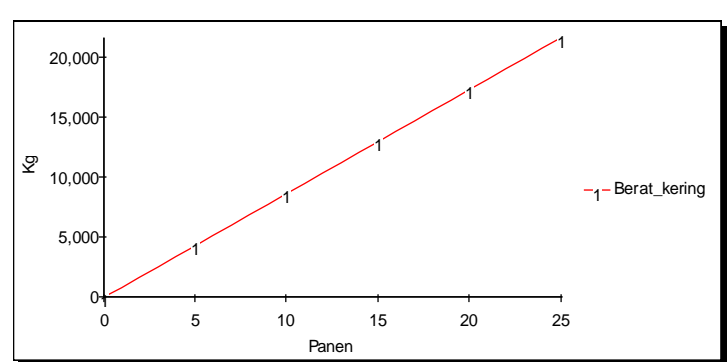

Gambar 5. Produksi berat kering panen rumput laut selama 25 kali panen tanpa penambahan modal tiap panen

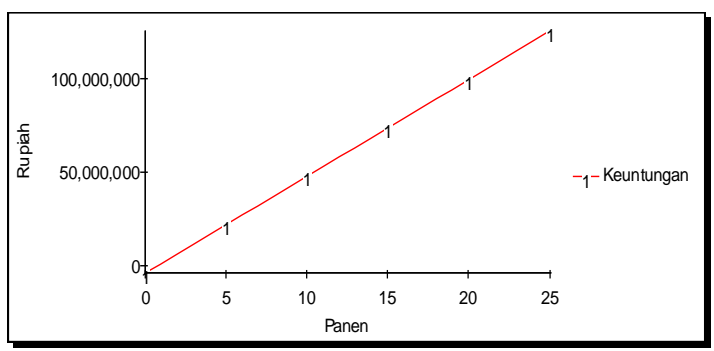

Gambar 6. Keuntungan budidaya rumput laut selama 25 kali panen tanpa penambahan modal tiap panen

Hasil simulasi model tanpa upaya pengembangan dapat dilihat pada Tabel 1, dan grafik keuntungan serta produksi (berat kering) diilustrasikan pada Gambar 5 dan 6. Pada Gambar 5 terlihat bahwa tanpa upaya pengembangan misalnya penambahan modal, produksi tetap akan meningkat secara linear sampai 25 kali panen sebesar $20.000 \mathrm{~kg}$. Hal ini berarti produksi bisa meningkat sebesar $4 \%$ dari produksi pertama kali panen yaitu $864 \mathrm{~kg}$ berat kering. Sedangkan keuntungan juga tetap bisa meningkat walaupun tanpa upaya pengembangan. Pada Gambar 6 terlihat keuntungan meningkat sebesar $0,52 \%$ dari panen pertama.

\section{Simulasi Model Pengembangan}

Simulasi pengembangan usaha budidaya rumput laut Eucheuma cottonii di Pantai Cipatujah yang dapat diterapkan berdasarkan hasil analisis permodelan sistem adalah sebagai berikut 
(A) Skenario 1: Penambahan bobot tebar rumput laut menjadi $30 \mathrm{~kg}$ per jalur tiap penanaman yang sebelumnya $10 \mathrm{~kg}$;

(B) Skenario 2: Penambahan modal $1 \%$ dan jalur $1 \%$ tiap penanaman;

(C) Skenario 3: Penambahan modal $1 \%$ dan jalur $2 \%$ tiap penanaman.

Ketiga skenario pengembangan ini diprediksi untuk 25 kali panen atau 5 tahun ke depan.

\section{Skenario model bobot tebar rumput laut $30 \mathrm{~kg}$ per jalur tiap penanaman}

Pada skenario model 1 ini berat bibit yang ditebar ditingkatkan dari $10 \mathrm{~kg}$ per jalur menjadi $30 \mathrm{~kg}$ per jalur, dengan kondisi modal dan total biaya adalah tetap (Tabel 2, Gambar 7 dan 8).

Tabel 2. Hasil simulasi pengembangan skenario 1 (Bobot tebar rumput laut $30 \mathrm{~kg}$ per jalur tiap penanaman)

\begin{tabular}{|c|c|c|c|c|}
\hline \{PANEN:?\} & MODAL & Total_Biaya & Berat_kering & Keuntungan \\
\hline 1 & $6,000,000.00$ & $4,530,681.82$ & $2,592.00$ & $11,021,318.2$ \\
\hline 2 & $6,000,000.00$ & $4,530,681.82$ & $5,184.00$ & $26,573,318.2$ \\
\hline 3 & $6,000,000.00$ & $4,530,681.82$ & $7,776.00$ & $42,125,318.2$ \\
\hline 4 & $6,000,000.00$ & $4,530,681.82$ & $10,368.00$ & $57,677,318.2$ \\
\hline 5 & $6,000,000.00$ & $4,530,681.82$ & $12,960.00$ & $73,229,318.2$ \\
\hline 6 & $6,000,000.00$ & $4,530,681.82$ & $15,552.00$ & $88,781,318.2$ \\
\hline 7 & $6,000,000.00$ & $4,530,681.82$ & $18,144.00$ & $104,333,318$ \\
\hline 8 & $6,000,000.00$ & $4,530,681.82$ & $20,736.00$ & $119,885,318$ \\
\hline 9 & $6,000,000.00$ & $4,530,681.82$ & $23,328.00$ & $135,437,318$ \\
\hline 10 & $6,000,000.00$ & $4,530,681.82$ & $25,920.00$ & $150,989,318$ \\
\hline 11 & $6,000,000.00$ & $4,530,681.82$ & $28,512.00$ & $166,541,318$ \\
\hline 12 & $6,000,000.00$ & $4,530,681.82$ & $31,104.00$ & $182,093,318$ \\
\hline 13 & $6,000,000.00$ & $4,530,681.82$ & $33,696.00$ & $197,645,318$ \\
\hline 14 & $6,000,000.00$ & $4,530,681.82$ & $36,288.00$ & $213,197,318$ \\
\hline 15 & $6,000,000.00$ & $4,530,681.82$ & $38,880.00$ & $228,749,318$ \\
\hline 16 & $6,000,000.00$ & $4,530,681.82$ & $41,472.00$ & $244,301,318$ \\
\hline 17 & $6,000,000.00$ & $4,530,681.82$ & $44,064.00$ & $259,853,318$ \\
\hline 18 & $6,000,000.00$ & $4,530,681.82$ & $46,656.00$ & $275,405,318$ \\
\hline 19 & $6,000,000.00$ & $4,530,681.82$ & $49,248.00$ & $290,957,318$ \\
\hline 20 & $6,000,000.00$ & $4,530,681.82$ & $51,840.00$ & $306,509,318$ \\
\hline 21 & $6,000,000.00$ & $4,530,681.82$ & $54,432.00$ & $322,061,318$ \\
\hline 22 & $6,000,000.00$ & $4,530,681.82$ & $57,024.00$ & $337,613,318$ \\
\hline 23 & $6,000,000.00$ & $4,530,681.82$ & $59,616.00$ & $353,165,318$ \\
\hline 24 & $6,000,000.00$ & $4,530,681.82$ & $62,208.00$ & $368,717,318$ \\
\hline 25 & $6,000,000.00$ & $4,530,681.82$ & $64,800.00$ & $384,269,318$ \\
\hline
\end{tabular}

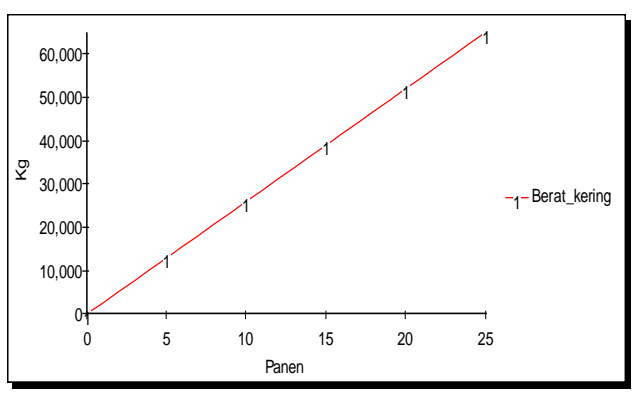

Gambar 7. Produksi berat kering panen rumput laut selama 25 kali panen dengan bobot tebar rumput laut $30 \mathrm{~kg}$ per jalur tiap penanaman

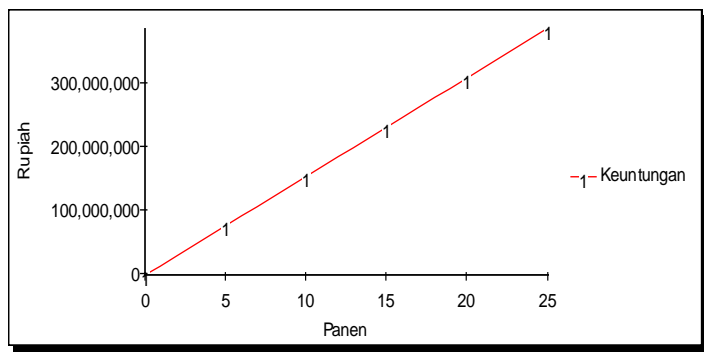

Gambar 8. Keuntungan panen rumput laut selama 25 kali panen dengan bobot tebar rumput laut $30 \mathrm{~kg}$ per jalur tiap penanaman

Skenario pengembangan ini memperlihatkan produksi dan keuntungan yang lebih besar dari skenario model dasar (tanpa pengembangan). Laju kenaikan produksi dan keuntungan pada setiap panen terlihat stabil. Dengan ditingkatkannya bobot bibit pada penebaran awal menjadi $30 \mathrm{~kg}$ per jalur pada tiap penanaman, maka kenaikan produksi pada panen ke-25 sebesar 33,3\% jika dibanding dengan skenario model dasar. Sedangkan keuntungan setelah pengembangan naik menjadi $32,5 \%$. dibandingkan dengan skenario model dasar.

\section{Skenario model penambahan modal $1 \%$ dan jalur $1 \%$ tiap penanaman}

Skenario model kedua ini disimulasikan dengan melakukan penambahan modal dan jalur sebesar $1 \%$ pada tiap waktu tanam. Hasil simulasi dan grafik produksi dan keuntungan dapat dilihat pada Tabel 3, Gambar 9 dan 10.

Tabel 3. Hasil simulasi pengembangan skenario 2 (penambahan modal $1 \%$ dan jalur $1 \%$ tiap penanaman)

\begin{tabular}{|c|c|c|c|c|}
\hline \{PANEN:?\} & MODAL & \begin{tabular}{|l|} 
Total Biaya \\
\end{tabular} & Berat_kering & Keuntungan \\
\hline $\begin{array}{r}1 \\
\end{array}$ & $6,600,000.00$ & $4,965,428.83$ & 864.00 & $218,571.17$ \\
\hline 2 & $7,260,000.00$ & $5,440,442.25$ & $1,810.91$ & $5,424,994.69$ \\
\hline 3 & $7,986,000.00$ & $5,959,161.25$ & $2,848.40$ & $11,131,222.3$ \\
\hline 4 & $8,784,600.00$ & $6,525,260.82$ & $3,984.81$ & $17,383,587.0$ \\
\hline & & & & $24,232,386.2$ \\
\hline 6 & $10,629,366.0$ & $7,815,504.62$ & $6,591.28$ & $31,732,155.4$ \\
\hline & $11,692,302.6$ & $8,548,203.43$ & $8,081.69$ & $39,941,946.4$ \\
\hline 8 & $12,861,532.9$ & $9,345,384.53$ & $9,711.83$ & $48,925,608.1$ \\
\hline 9 & $14,147,686.1$ & $10,211,903.4$ & $11,493.99$ & $58,752,065.5$ \\
\hline 10 & $15,562,454.8$ & $11,152,822.6$ & $13,441.40$ & $69,495,592.4$ \\
\hline 11 & $17,118,700.2$ & $12,173,387.4$ & $15,568.24$ & $81,236,072.0$ \\
\hline 12 & $18,830,570.3$ & $13,278,994.9$ & $17,889.71$ & $94,059,237.9$ \\
\hline 13 & $20,713,627.3$ & $14,475,152.4$ & $20,422.01$ & $108,056,889$ \\
\hline 14 & $22,784,990.0$ & $15,767,426.1$ & $23,182.42$ & $123,327,065$ \\
\hline 15 & $25,063,489.0$ & $17,161,379.1$ & $26,189.26$ & $139,974,179$ \\
\hline 16 & $27,569,837.9$ & $18,662,496.1$ & $29,461.93$ & $158,109,089$ \\
\hline 17 & $30,326,821.7$ & $20,276,096.1$ & $33,020.86$ & $177,849,092$ \\
\hline 18 & $33,359,503.9$ & $22,007,231.2$ & $36,887.51$ & $199,317,838$ \\
\hline 19 & $36,695,454.3$ & $23,860,572.7$ & $41,084.29$ & $222,645,141$ \\
\hline & $40,364,999.7$ & $25,840,284.5$ & $45,634.49$ & $247,966,664$ \\
\hline 21 & $44,401,499.7$ & $27,949,885.2$ & $50,562.23$ & $275,423,482$ \\
\hline 22 & $48,841,649.6$ & $30,192,101.1$ & $55,892.26$ & $305,161,487$ \\
\hline 23 & $53,725,814.6$ & $32,562,594.1$ & $61,649.89$ & $337,336,755$ \\
\hline 24 & $59,098,396.1$ & $35,059,157.9$ & $67,859.57$ & $372,098,267$ \\
\hline 25 & $65,008,235.7$ & $37,679,045.2$ & $74,545.34$ & $409,593,021$ \\
\hline & & & & \\
\hline
\end{tabular}




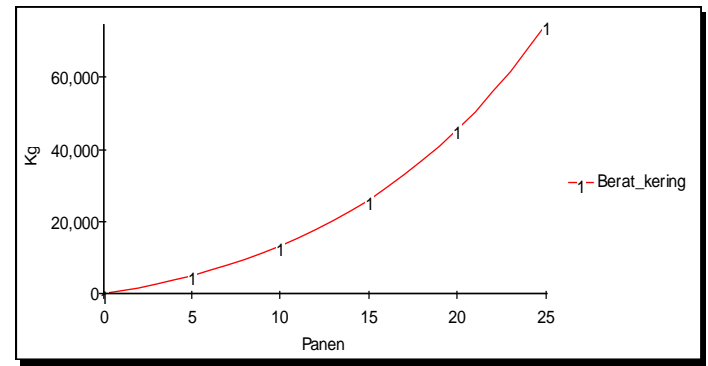

Gambar 9. Produksi berat kering panen rumput laut selama 25 kali panen dengan penambahan modal $1 \%$ dan $1 \%$ jalur tiap panen

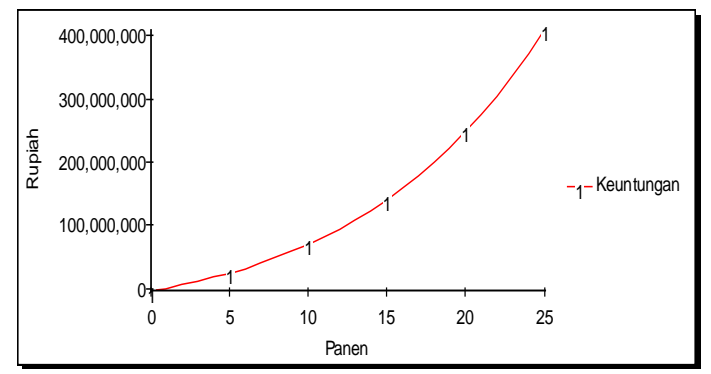

Gambar 10. Keuntungan panen rumput laut selama 25 kali panen dengan penambahan modal $1 \%$ dan $1 \%$ jalur tiap panen

Pada grafik produksi dan keuntungan (Gambar 9 dan 10) terlihat terjadi peningkatan dengan model kurva hiperbola, dimana ini mengindikasikan pada awal-awal panen laju kenaikannya agak lambat tetapi setelah panen ke 15 terlihat laju kenaikan produksi dan keuntungan makin cepat hingga panen ke 25. Produksi dan keuntungan pada skenario 2 ini tidak lebih baik daripada skenario 1, dimana dapat dilihat dari angka produksi dan keuntungan yang lebih kecil jika dibanding dengan skenario 1 . Nilai pada panen ke-23 tidak jauh beda dengan skenario 1, panen ke-24 baru melebihi skenario 1. Sehingga dapat dikatakan penambahan modal dan jalur sebesar $1 \%$ tidak meningkatkan produksi dan keuntungan secara signifikan.

\section{Skenario model penambahan modal $1 \%$ dan jalur $2 \%$ tiap penanaman \\ Model pengembangan pada} skenario ke-3 ini adalah dengan menambahkan modal sebesar $1 \%$ dan jalur sebesar $2 \%$ pada tiap waktu tanam. Hasil simulasi model pengembangan skenario 3 dapat dilihat pada Tabel 4, Gambar 11 dan Gambar 12

Tabel 4. Hasil simulasi model pengembangan skenario 3 (penambahan modal $1 \%$ dan jalur $2 \%$ tiap penanaman)

\begin{tabular}{|r|c|r|r|r||}
\hline \{PANEN:?\} & MODAL & Total_Biaya & Berat_kering & \multicolumn{1}{c|}{ Keuntungan } \\
\hline 1 & $6,600,000.00$ & $5,135,582.21$ & 864.00 & $48,417.79$ \\
\hline 2 & $7,260,000.00$ & $5,772,913.13$ & $1,843.35$ & $5,287,213.08$ \\
\hline 3 & $7,986,000.00$ & $6,436,381.17$ & $2,944.25$ & $11,229,104.4$ \\
\hline 4 & $8,784,600.00$ & $7,136,841.59$ & $4,171.66$ & $17,893,142.6$ \\
\hline 5 & $9,663,060.00$ & $7,867,573.83$ & $5,532.66$ & $25,328,374.9$ \\
\hline 6 & $10,629,366.0$ & $8,620,271.62$ & $7,033.00$ & $33,577,744.4$ \\
\hline 7 & $11,692,302.6$ & $9,390,299.06$ & $8,676.89$ & $42,671,020.1$ \\
\hline 8 & $12,861,532.9$ & $10,193,316.9$ & $10,467.61$ & $52,612,369.7$ \\
\hline 9 & $14,147,686.1$ & $11,024,485.6$ & $12,411.48$ & $63,444,380.4$ \\
\hline 10 & $15,562,454.8$ & $11,878,068.1$ & $14,513.84$ & $75,204,999.5$ \\
\hline 11 & $17,118,700.2$ & $12,742,799.8$ & $16,778.99$ & $87,931,137.2$ \\
\hline 12 & $18,830,570.3$ & $13,608,144.8$ & $19,209.04$ & $101,646,086$ \\
\hline 13 & $20,713,627.3$ & $14,465,633.7$ & $21,804.11$ & $116,359,018$ \\
\hline 14 & $22,784,990.0$ & $15,310,304.1$ & $24,562.70$ & $132,065,906$ \\
\hline 15 & $25,063,489.0$ & $16,140,278.6$ & $27,482.37$ & $148,753,961$ \\
\hline 16 & $27,569,837.9$ & $16,948,932.6$ & $30,560.32$ & $166,412,992$ \\
\hline 17 & $30,326,821.7$ & $17,730,254.2$ & $33,792.48$ & $185,024,616$ \\
\hline 18 & $33,359,503.9$ & $18,479,017.7$ & $37,173.63$ & $204,562,785$ \\
\hline 19 & $36,695,454.3$ & $19,190,908.5$ & $40,697.58$ & $224,994,562$ \\
\hline 20 & $40,364,999.7$ & $19,862,594.8$ & $44,357.28$ & $246,281,087$ \\
\hline 21 & $44,401,499.7$ & $20,491,747.0$ & $48,145.07$ & $268,378,689$ \\
\hline 22 & $48,841,649.6$ & $21,077,006.9$ & $52,052.84$ & $291,240,058$ \\
\hline 23 & $53,725,814.6$ & $21,617,918.4$ & $56,072.22$ & $314,815,429$ \\
\hline 24 & $59,098,396.1$ & $22,114,826.5$ & $60,194.76$ & $339,053,714$ \\
\hline 25 & $65,008,235.7$ & $22,568,758.0$ & $64,412.05$ & $363,903,537$ \\
\hline & & & & \\
\hline & & & & \\
\hline
\end{tabular}

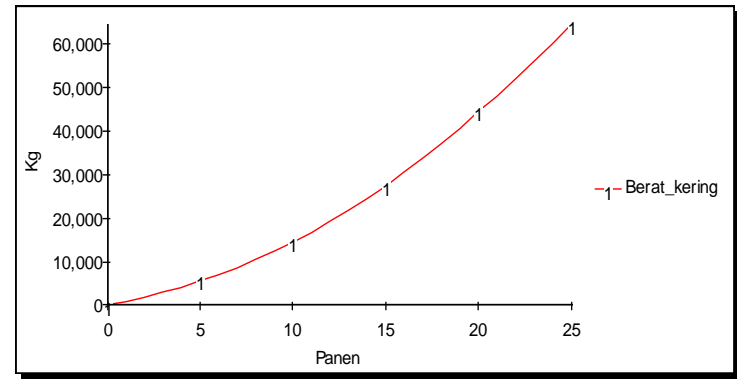

Gambar 11. Produksi berat kering panen rumput laut selama 25 kali panen dengan penambahan modal $1 \%$ dan $2 \%$ jalur tiap panen

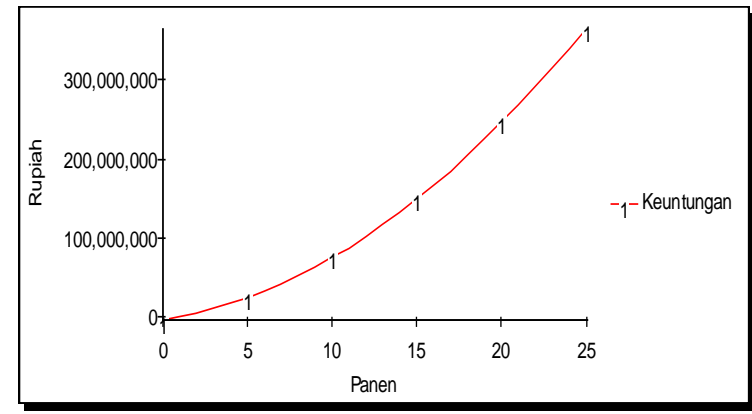

Gambar 12. Keuntungan panen rumput laut selama 25 kali panen dengan penambahan modal $1 \%$ dan $2 \%$ jalur tiap panen

Grafik produksi dan keuntungan pada skenario 3 memperlihatkan bentuk yang hampir sama dengan skenario 2. Akan tetapi usaha pengembangan pada skenario 3 tidak menunjukkan hasil yang lebih 
bagus dari skenario 1 dan 2, baik dari segi produksi maupun keuntungan. Terlihat bahwa keuntungan dan produksi lebih rendah dari skenario 1 dan 2 .

\section{KESIMPULAN DAN SARAN}

Pemodelan sistem pengembangan usaha budidaya rumput laut Eucheuma cottonii di Pantai Cipatujah, Kabupaten Tasikmalaya merupakan suatu kajian rekayasa sistem yang dapat digunakan untuk merancang usaha budidaya sehingga diperoleh hasil yang optimal.

Hasil simulasi model ketiga skenario serta skenario dasar menunjukkan bahwa model skenario 1, yaitu penambahan bobot bibit menjadi $30 \mathrm{~kg}$ per jalur menunjukkan hasil yang paling bagus jika dibanding dengan model dasar serta skenario 2 dan 3.

Dengan adanya pendekatan model system ini diharapkan dapat diterapkan di di pantai Cipatujah Kab. Tasikmalaya olah investor ataupun pemerintah setempat.

\section{DAFTAR PUSTAKA}

Anonim, 2006. SPC Heads of Fisheries Meeting on 3-7th April 2006, Noumea, New Caledonia.

Anggadiredja, J.T., A. Zatnika, H. Purwoto, dan S. Istini. 2006. Rumput Laut: Pembudidayaan, Pengolahan, \& Pemasaran Komoditas Perikanan Potensial. Penebar Swadaya. Jakarta.

Hardjomidjojo, H. 2004. Konsep Sistem. Bahan Kuliah Pasca Sarjana, Jurusan Teknologi Agroindustri, Institut Pertanian Bogor.

Muhammadi, E. Aminullah, dan B. Susilo. 2001. Analisis Sistem Dinamis. UMJ Press, Jakarta. 